\title{
Evaluating Irrigation and Farming Systems with Solar MajiPump in Ethiopia
}

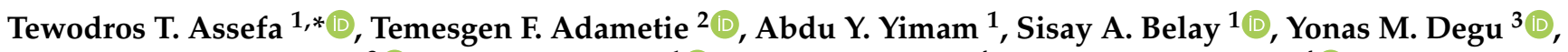 \\ Solomon T. Hailemeskel ${ }^{3}$ (D), Seifu A. Tilahun ${ }^{1}$ (D), Manuel R. Reyes ${ }^{4}$ and P. V. Vara Prasad ${ }^{4}$ (D) \\ 1 Faculty of Civil and Water Resource Engineering, Bahir Dar Institute of Technology, Bahir Dar University, \\ Bahir Dar 26, Ethiopia; abdukemer62@gmail.com (A.Y.Y.); sisayasress@gmail.com (S.A.B.); \\ sat86@cornell.edu (S.A.T.) \\ 2 Department of Irrigation and Drainage, Pawe Agricultural Research Center, \\ Ethiopian Institute of Agricultural Research, Pawe 25, Ethiopia; temesgenfentahun09@gmail.com \\ 3 Faculty of Mechanical and Industrial Engineering, Bahir Dar Institute of Technology, Bahir Dar University, \\ Bahir Dar 26, Ethiopia; yonasmitiku2000@gmail.com (Y.M.D.); soltektata@gmail.com (S.T.H.) \\ 4 Sustainable Intensification Innovation Lab and Department of Agronomy, Kansas State University, \\ Manhattan, KS 66506, USA; mannyreyes@ksu.edu (M.R.R.); vara@ksu.edu (P.V.V.P.) \\ * Correspondence: ttaffese@gmail.com; Tel.: +251-91-210-0610
}

Citation: Assefa, T.T.; Adametie, T.F.; Yimam, A.Y.; Belay, S.A.; Degu, Y.M.; Hailemeskel, S.T.; Tilahun, S.A.; Reyes, M.R.; Prasad, P.V.V. Evaluating Irrigation and Farming Systems with Solar MajiPump in Ethiopia. Agronomy 2021, 11, 17. https://dx.doi.org/10.33 90/agronomy11010017

Received: 25 November 2020 Accepted: 21 December 2020 Published: 23 December 2020

Publisher's Note: MDPI stays neutral with regard to jurisdictional claims in published maps and institutional affiliations.

Copyright: (c) 2020 by the authors. Licensee MDPI, Basel, Switzerland. This article is an open access article distributed under the terms and conditions of the Creative Commons Attribution (CC BY) license (https: / / creativecommons.org/ licenses/by/4.0/).

\begin{abstract}
Small-scale irrigation in Ethiopia is a key strategy to improve and sustain the food production system. Besides the use of surface water for irrigation, it is essential to unlock the groundwater potential. It is equally important to use soil management and water-saving systems to overcome the declining soil fertility and the temporal water scarcity in the region. In this study, the solar MajiPump was introduced to enable dry season crop production in Ethiopia using shallow groundwater sources. The capacity of the MajiPumps (MP400 and MP200) was tested for the discharge head and discharge using three types of solar panels ( $150 \mathrm{~W}$ and $200 \mathrm{~W}$ rigid, and $200 \mathrm{~W}$ flexible). Besides, drip irrigation and conservation agriculture (CA) farming systems were evaluated in terms of water productivity and crop yield in comparison to the farmers' practice (overhead irrigation and tilled farming system). Results indicated that the maximum discharge head capacity of the MajiPumps was $18 \mathrm{~m}, 14 \mathrm{~m}, 10 \mathrm{~m}$ when using MP400 with $200 \mathrm{~W}$ rigid, MP400 with $200 \mathrm{~W}$ flexible, and MP200 with $150 \mathrm{~W}$ rigid solar panels, respectively. The corresponding MajiPump flow rates ranged from $7.8 \mathrm{~L} / \mathrm{min}$ to $24.6 \mathrm{~L} / \mathrm{min}$, $3 \mathrm{~L} / \mathrm{min}$ to $25 \mathrm{~L} / \mathrm{min}$, and $3.6 \mathrm{~L} / \mathrm{min}$ to $22.2 \mathrm{~L} / \mathrm{min}$, respectively. Compared to farmer's practice, water productivity was significantly improved under the CA farming and the drip irrigation systems for both irrigated vegetables (garlic, onion, cabbage, potato) and rainfed maize production. The water productivity of garlic, cabbage, potato, and maize was increased by $256 \%, 43 \%, 53 \%$, and $9 \%$, respectively, under CA as compared to conventional tillage (CT) even under overhead irrigation. Thus, farmers can obtain a significant water-saving benefit from CA regardless of water application systems. However, water and crop productivity could be further improved in the combined use of MajiPump with CA and drip irrigation (i.e., 38\% and 33\% water productivity and $43 \%$ and $36 \%$ crop productivity improvements were observed for potato and onion, respectively). Similarly, compared to $\mathrm{CT}$, the use of CA significantly increased garlic, cabbage, potato, and maize yield by $170 \%, 42 \%$, $43 \%$, and $15 \%$, respectively under the MajiPump water-lifting system. Overall, the solar-powered drip irrigation and CA farming system were found to be efficient to expand small-scale irrigation and improve productivity and livelihoods of smallholder farmers in Ethiopia.
\end{abstract}

Keywords: solar MajiPump; water and crop productivity; small-scale irrigation; conservation agriculture; Ethiopia

\section{Introduction}

Agriculture has been practiced for centuries and is regarded as the main source of food and income for the rural communities of Ethiopia [1], which accounts for more than 
$80 \%$ of the total population [2]. However, rainfed agriculture has frequently suffered from uneven distribution of rainfall and frequent drought shocks, leading to food insecurity of the poor rural communities [3,4]. In response to such recurrent challenges, smallscale irrigation has been considered as one of the main strategies to alleviate food and income shortages [5,6] and enhance the livelihoods of farmers in Ethiopia [7-12]. Smallscale irrigation often refers to distributed irrigation, small private irrigation, smallholder irrigation, or farmer-led irrigation [13]. In recent years, there is a keen interest in small-scale irrigation due to its cost-effectiveness [14] and sustainable management as compared to large-scale irrigation [13]. It is believed that Ethiopia has more than 6 million hectares of land that is appropriate for small-scale irrigation use [15] and ample water resources suitable for irrigation [15-18]. Nevertheless, irrigated agriculture comprises only $3 \%$ of the national food production, using less than $5 \%$ of the cultivated land for irrigation $[4,19]$ due to various constraints. Xie et al. [13] depicted that Ethiopia has the potential to add about 1 million ha of land irrigated by small-scale irrigation systems by 2030.

Despite the considerably large potential for irrigation, there are several challenges for the wider adoption of small-scale irrigation in Ethiopia. Some of these challenges include temporal water scarcity [10], poor management of soil and water [7,11,20], lack of water storage facilities, limited opportunities for gravity-fed irrigation, lack of access to irrigation technology, high initial and operation cost of irrigation technologies, and limited capital investments $[15,19,21]$. On the other hand, limited rainfall and prolonged dry spells entail the need for the efficient use of both surface and groundwater sources, conservation agricultural (CA) practices, efficient water distribution and application systems [22-25]. It is evidenced that in Ethiopia, CA practice provides dual benefits of improved water $[11,16,22,25-28]$ and improved soil conservation [29]. In terms of water application technology, the drip irrigation system is considered the most efficient and water-saving system $[30,31]$. CA in this study refers to the minimum soil disturbance with no-till practice, year-round organic mulch cover with grass, and diverse cropping in rotation, whereas $\mathrm{CT}$ refers to the traditional tillage with no-organic mulch cover and diverse cropping in rotation.

Groundwater is believed to be stable in the face of climate change as compared to surface water and would serve as a source of irrigation $[15,32,33]$. The role of efficient, labor-saving, and cost-effective water-lifting technologies is vital in unlocking groundwater potential for smallholder farmers [34]. Treadle pumps, rope and washer, pulley, and bucket have been used by smallholders in Ethiopia as a means of water-lifting technologies. However, these technologies are labor-intensive and only just used as a means of waterlifting beyond domestic use (e.g., drinking and cooking), and not for irrigation. Motor pumps (diesel or petrol) have been used by some farmers for irrigation but constrained due to high energy demand, limited access to fuel, and the alarming increase in the cost of fuel, and thus leading to increased risks in irrigated crop production [34]. In some urban areas, electric motor pumps might be feasible and used for urban agriculture. However, electricity access is rare for the rural community of Ethiopia [35]. In response to such challenges, several researchers suggested the use of solar pumps due to their high labor productivity, environmental sustainability, and use of renewable energy sources [36-38]. Ethiopia, as a tropical region, has ample solar energy $[39,40]$ that can be captured for water lifting and pumping systems.

The MajiPump is a solar-powered water-lifting technology that was introduced in Ethiopia in 2017 by the Appropriate Scale Mechanization Consortium of the Feed the Future Sustainable Intensification Innovation Lab (SIIL). The solar MajiPump, a submersible pump, uses solar energy to extract water from wells and surface ponds. A solar panel is connected to the MajiPump by an electric cable driven by the direct current (DC). However, the discharge head and discharge capacity of the MajiPump is not known beyond the company specification. Evaluating the use of these pumps under field conditions and their impact on crop yields is critical for scaling and adoption of these technologies. Widescale use of efficient water applications in combination with improved crop and soil water management 
technologies are vital for income generation and increase resilience in the face of climate change, and to reverse the decline of soil fertility. Such systems need to be tested for both vegetable production systems, which are becoming more popular due to demand for vegetables from urban markets and for high-value grain crops such as maize (Zea mays L.). Smallholder vegetable production is considered as a strategic approach to minimize children's death and stunting caused by malnutrition, which is a serious challenge in Ethiopia [41], by providing healthy and nutritious diets. Thus, the objectives of this study were to evaluate small-scale irrigation package: (1) MajiPumps (MP400 and MP200) for its discharge head and discharge capacity with different solar panels; (2) drip water application system with the common farmer's overhead irrigation practice using hose; and (3) CA with farmer's conventional tillage $(\mathrm{CT})$ practice; in terms of water productivity and yields of key crops [garlic (Allium sativium L.), onion (Allium cepa L.), cabbage (Brassica oleracea L. var. captata), potato (Solanum tuberosum L.), and maize]. The results from this study would assist decision-makers and other stakeholders in scaling small-scale irrigation technologies and exploring groundwater potential in Ethiopia.

\section{Materials and Methods}

\subsection{Study Area}

This study was conducted in the central Ethiopian highlands at two experimental sites: Affesa in Dangila district and Alefa in Bure district (Figure 1). Affesa ( $36.83^{\circ} \mathrm{N}$, $\left.11.25^{\circ} \mathrm{E}\right)$ and Alefa $\left(37.06^{\circ} \mathrm{N}, 10.62^{\circ} \mathrm{E}\right)$ sites are located about $80 \mathrm{~km}$ and $150 \mathrm{~km}$ southwest of Bahir Dar, respectively. The elevation of Affesa site ranges from 2132 to $2219 \mathrm{~m}$ above MSL, whereas Alefa site elevation ranges from 1983 to 2033 m above MSL. Both Dangila and Bure districts are categorized under moist sub-tropical regions. Dangila has an average annual rainfall of $1578 \mathrm{~mm}$ and a mean annual temperature of $17^{\circ} \mathrm{C}$ [42], whereas, the mean annual rainfall and temperature in Bure ranges from $1386 \mathrm{~mm}$ to $1757 \mathrm{~mm}$ and $14^{\circ} \mathrm{C}$ to $24{ }^{\circ} \mathrm{C}$, respectively [43]. Based on soil laboratory analysis, clay soil is the dominant soil texture in Affesa (46\% clay and 36\% silt) and the soil type in Alefa is dominated by loam soil (44\% sand and 29\% silt). The dominant rainfed crops in both Dangila and Bure districts include maize, millets (sorghum: Sorghum bicolor L., or pearl millet: Panicum sp.), barley (Hordeum vulgare L.), teff [Eragrostis tef (Zucc.) Trotter], and wheat (Triticum aestivum L.), [44]. While, onion, potato, cabbage, pepper, tomato, and garlic are the dominant irrigated vegetables in both Dangila and Bure district [22,45]. In the Affesa site, farmers used to practice irrigation using river sources, whereas groundwater use was limited to domestic purposes in both sites due to lack of access to affordable water-lifting technology.

\subsection{Experimental Design}

The experiment was laid as a paired t-design to compare the effects of conservation practices and irrigation systems. The paired t-test is mathematically powerful in comparing two-paired measurements that have intrinsic relationships and allows good control of individual differences without necessarily having a large sample size [46]. De Winter [47] proved the applicability of paired t-test as low as two replicates. Several studies, including Yimam et al. [22], Belay et al. [26], and Assefa et al. [11] have used paired-t design for similar purposes. The experimental design and setup were described for each site (i.e., Alefa and Affesa) separately as shown below. 


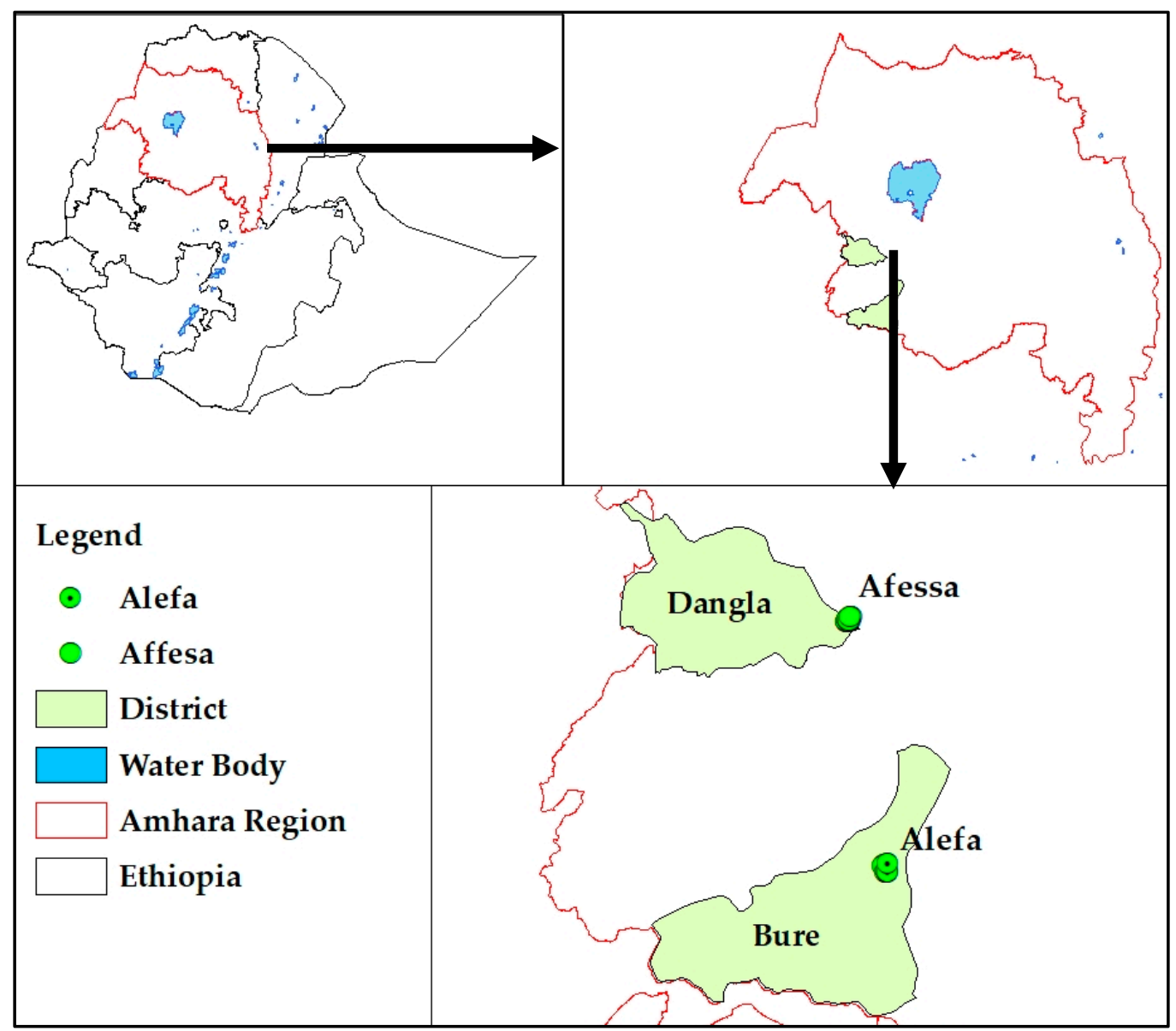

Figure 1. Location map of experimental sites in the northern part of Ethiopia.

\section{Alefa site}

CA was the treatment and CT was the control in which each participant was involved in both (CA and CT) practice with overhead irrigation (hose). A total of 10 replicates (i.e., farmers) were used. The size of each plot was $100 \mathrm{~m}^{2}$ (Figure 2a), which then equally divided; $50 \mathrm{~m}^{2}$ for each management (i.e., randomly assigned to CA and CT). The $100 \mathrm{~m}^{2}$ plot has 10 beds with $30 \mathrm{~cm}$ furrows in between (i.e., $70 \mathrm{~cm}$ by $10 \mathrm{~m}$ bed size and $30 \mathrm{~cm}$ by $10 \mathrm{~m}$ furrow size). The experimental plots are not evenly distributed, approximately the distance between the plots ranges from $300 \mathrm{~m}$ to more than $1 \mathrm{~km}$. CA was evaluated against CT for their impacts on water productivity, crop growth characteristics, and yield.

Affesa site

Drip irrigation was the treatment, and overhead irrigation (hose) was the control in which each participant was involved in both drip and overhead irrigation under CA practice (Figure 2b). A total of 10 replicates (i.e., farmers) were used each having $100 \mathrm{~m}^{2}$ plot size. The size of each plot was equally divided; $50 \mathrm{~m}^{2}$ for each management (i.e., randomly assigned to drip and overhead irrigation). Similar to Alefa, the $100 \mathrm{~m}^{2}$ plot has 10 beds with $30 \mathrm{~cm}$ furrows in between. In this case, drip irrigation was evaluated against overhead irrigation for their impacts on water productivity, crop growth characteristics, and yield. Besides, maize-forage vetch (Vicia sp.) inter-cropping (500 $\mathrm{m}^{2}$ in size as shown in Figure 2c) was introduced during the rainy season (i.e., $250 \mathrm{~m}^{2}$ with CA and another $250 \mathrm{~m}^{2}$ with CT practice at random) to provide an alternative source of mulch for conservation practice and simultaneously evaluate the effect of CA on rainfed maize productivity. 


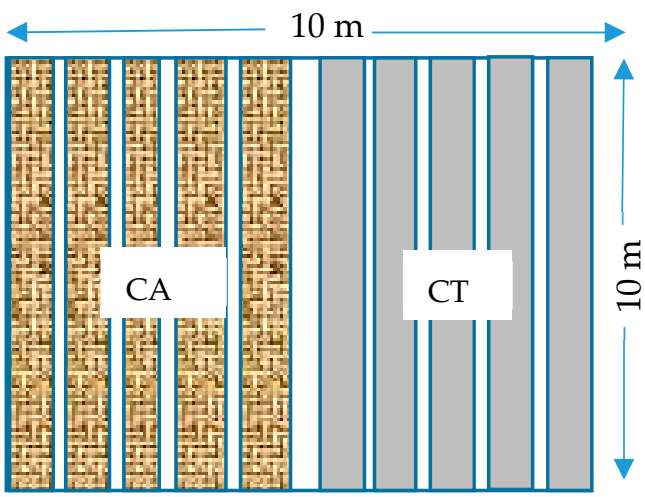

(a) CA versus CT (overhead irrigated)

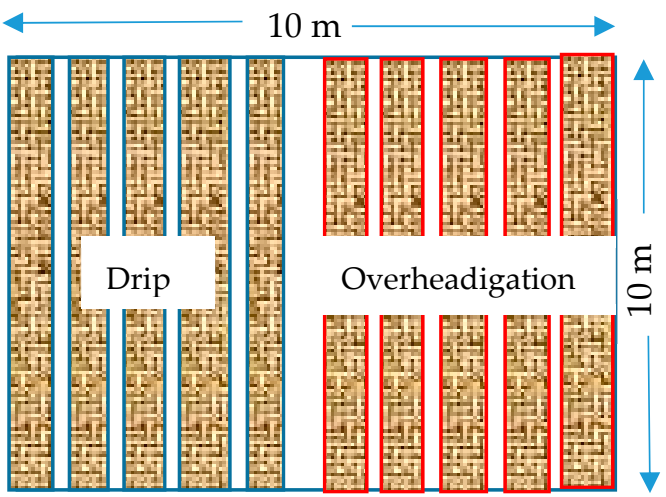

(b) Drip versus overhead irrigation (both CA)

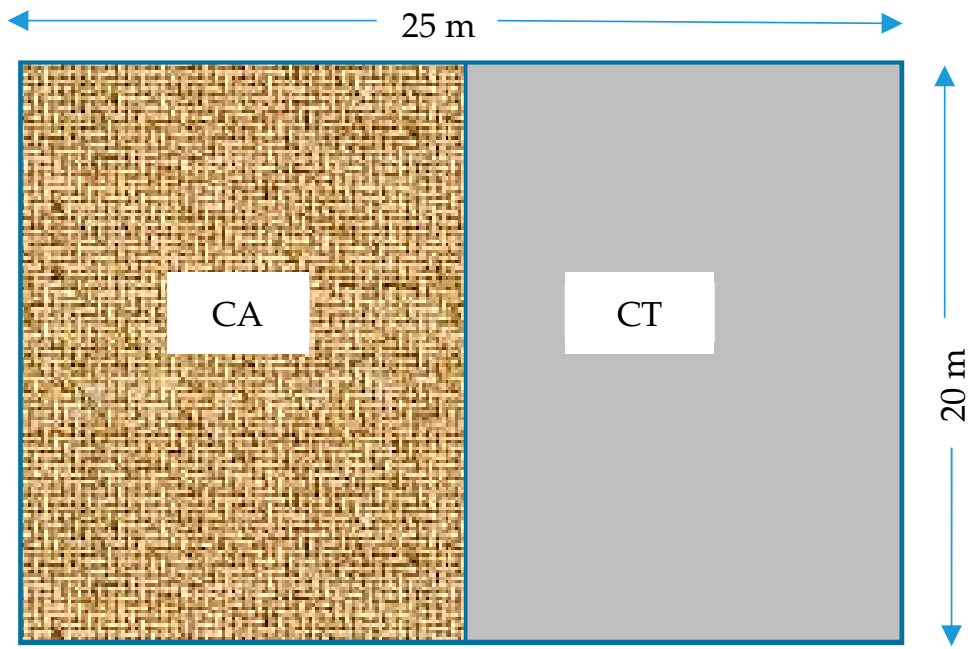

(c) CA versus CT under (rainfed)

Figure 2. Experimental design: (a) conservative agriculture (CA) versus conventional tillage (CT) both under overhead irrigation using hose, (b) drip versus overhead irrigation using hose both under CA, (c) CA versus CT intercropped with forage vetch under rainfed maize production

A total of 20 farmers participated in this on-farm experiment: 10 farmers in Alefa and 10 farmers in Affesa. A series of discussions were conducted with the local government and community leaders to select potential farmers for this research. Farmer's willingness to participate in this research was confirmed through a focus group discussion. The availability of shallow groundwater, a $100 \mathrm{~m}^{2}$ plot for vegetable production, and a $500 \mathrm{~m}^{2}$ plot for maize-forage production that was close to the household or at a walking distance was considered as additional criteria as a home gardening principle [48] to identify potential farmers. On the $100 \mathrm{~m}^{2}$ vegetable plot, a total of 10 beds $(70 \mathrm{~cm}$ by $10 \mathrm{~m})$ were prepared with $30 \mathrm{~cm}$ furrows in between. Farmers produced various vegetables (garlic, onion, cabbage, and potato) in the dry season (2018 to 2020) with irrigation. Each farmer used a solar MajiPump to extract water from shallow groundwater well to an elevated (about $1.5 \mathrm{~m}$ high from the ground) water storage tank (1000 L in size). Water was then applied to the plots from the water storage tanks through gravity using the drip system or overhead using a hose, depending on the experimental design. In the rainy season, farmers grew maize, and then inter-crop forage vetch after the maize reaches the maturity stage. The vetch forage production uses partly rainfall and then residual moisture from the rainy season. The variety of seeds for the vegetables, maize, and forage vetch was the same for all farmers. 


\subsection{Soil Physico-Chemical Properties}

Soil samples were taken from both Alefa and Affesa sites before the intervention of our treatments mainly to observe if there was variability between experimental plots for a paired t-design. Five sampling plots were randomly selected from a total of 10 plots at each site. Considering the maximum root depth of the various crops grown in the study sites (i.e., onion, garlic, potato, cabbage, and maize) in Yimam et al. [22], Iwama [49], and Gao, et al. [50], and the soil layer classification in Westerveld, et al. [51] and Hsu, et al. [52], soil samples were collected from three depths (i.e., 0-30 cm, 30-60 cm, and 60-90 cm). A total of 30 soil samples were collected: 15 samples from each experimental site. Soil laboratory analysis was conducted at Amhara Design and Supervision Works Enterprise (ADSWE) to determine the various physio-chemical properties (i.e., field capacity, permanent wilting point, soil texture, available organic matter, $\mathrm{pH}$, total $\mathrm{N}$, available $\mathrm{P}$, and available $\mathrm{K}$ ). A representative soil mass of about $1 \mathrm{~kg}$ was sampled from each plot. Soil texture was measured using hydrometer, while field capacity and wilting point were determined using pressure (porous) plate apparatus. The details of each laboratory analysis and approach used by ADSWE can be found from Tesema et al. [53]. Coefficient of variation was calculated from the 15 soil samples at each experimental site (i.e., Alefa and Affesa) for each soil physio-chemical properties.

\subsection{Climate Data}

Climatic data (rainfall, maximum and minimum temperature, wind speed, sunshine hour, relative humidity) were collected from the nearby meteorological station, Dangila for Affesa site, and Bure for Alefa site. The CROPWAT 8 model was used to estimate the reference evapotranspiration (ETo) using the Penman-Monteith method [54]. Mean monthly rainfall reaches its maximum value in July (401 $\mathrm{mm}$ in Affesa and $301 \mathrm{~mm}$ in Alefa), and mean month evapotranspiration reaches its maximum value in April (112 mm in Affesa and $128 \mathrm{~mm}$ in Alefa) as shown in Figure 3. Spatial and temporal rainfall variability is high demanding irrigation to prevent crop failure and increase the cycle of crop production $[11,55]$. Irrigation use for dry season vegetable production in the study sites ranges from October to June.

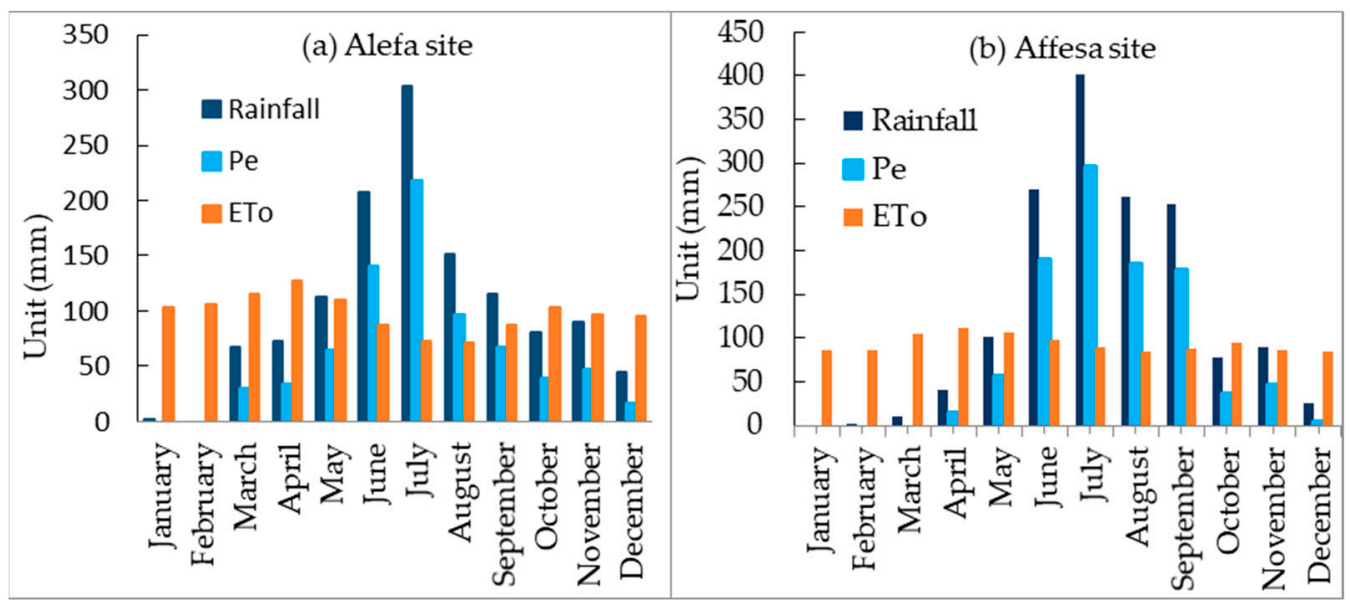

Figure 3. Climatic characteristics (rainfall; Pe, effective rainfall; ETo, reference crop transpiration) at the research sites of (a) Alefa and (b) Affesa (2018-2020).

Effective rainfall $(\mathrm{Pe})$ was determined using the United States Department of Agriculture Soil Conservation Service (USDA-SCS) method [56,57] as shown in (Equation (1)). The 
effective rainfall was used later to determine water productivity for each crop under both irrigated and rainfed systems.

$$
\left(\begin{array}{cc}
P e=0.8 P-25 & P>75 \mathrm{~mm} / \text { month } \\
P e=0.6 P-10 & P<75 \mathrm{~mm} / \text { month }
\end{array}\right)
$$

where $P e$ and $P$ are effective rainfall and precipitation in $\mathrm{mm} / \mathrm{month}$, respectively.

\subsection{Agronomic Data}

Garlic, cabbage, potato, onion, and maize crops were grown in the study sites. Farmers at each experimental site (i.e., Alefa or Affesa) grew the same crop during each cropping cycle. Activities including planting, mulch application, fertilizer, and pesticide application and crop harvest information were monitored for each crop during each cropping cycle (Table 1). On average, $1 \mathrm{~kg} \mathrm{~m}^{-2}$ of dried grass mulch was applied for CA plots. Farmers applied Urea (46-0-0: N-P-K) fertilizer at a rate of $100 \mathrm{~kg} \mathrm{ha}^{-1}$ for irrigated onion and potato. For rainfed maize, $240 \mathrm{~kg} \mathrm{ha}^{-1}$ of DAP (18-46-0: N-P-K), $500 \mathrm{~kg} \mathrm{ha}^{-1}$ of Urea fertilizer, and $5 \mathrm{~L} \mathrm{ha}^{-1}$ of Diazinon $60 \%$ chemical were applied. Crop characteristics such as plant height, potato tuber diameter, garlic and onion bulb diameter, cabbage head diameter, and crop/vegetable yield were recorded. Plant height was monitored every week. Measuring tape and Caliper were used to measure plant height and diameter, respectively. The digital balance was used to determine weight crop yield. A paired t-test was used at a $5 \%$ significance level to determine the effects of management practices on all crop characteristics.

\subsection{Solar MajiPump and Its Applicability}

In this study, two types (i.e., MP400 and MP200) of submersible brushless DC motor MajiPumps were used. Both MP400 (1.8 kg of mass) and MP200 (1.5 kg of mass) pumps have similar looks from the outside (Figure $4 \mathrm{a}$ ). The basic difference between the two pumps is the water-lifting capacity; MP400 could lift to $25 \mathrm{~m}$ discharge head using a $160 \mathrm{~W}$ (24 VDC) panel whereas the MP200 pump could lift to $10 \mathrm{~m}$ using an $80 \mathrm{~W}$ (12 VDC) panel. Both pumps could deliver $34 \mathrm{~L} / \mathrm{min}$ flow rate for open flow. Two types of solar panels were used for the MP400 pump (monocrystalline $200 \mathrm{~W}$ rigid panel and two flexible panels of $200 \mathrm{~W}$ connected in series), and a monocrystalline $150 \mathrm{~W}$ rigid panel was used for the MP200 pump. The monocrystalline $200 \mathrm{~W}$ rigid panel is $1.58 \mathrm{~m}$ by $0.85 \mathrm{~m}$ in size with $12.7 \mathrm{~kg}$ total mass (Figure $4 \mathrm{~b}$ ). Whereas the monocrystalline $150 \mathrm{~W}$ rigid panel is $1.48 \mathrm{~m}$ by $0.67 \mathrm{~m}$ in size with $10.22 \mathrm{~kg}$ total mass (Figure $4 \mathrm{~d}$ ). The thin film (amorous) flexible $100 \mathrm{~W}$ solar panel (Figure $4 \mathrm{~d}$ ) is $1.05 \mathrm{~m}$ by $0.54 \mathrm{~m}$ size and $1.4 \mathrm{~kg}$ of mass each. 
Table 1. Crop rotation and management activities at Affesa and Alefa experimental sites.

\begin{tabular}{|c|c|c|c|}
\hline Site & Vegetable & Management Activity & Date \\
\hline \multirow{12}{*}{ Alefa } & \multirow{4}{*}{$\begin{array}{l}\text { Irrigated Garlic } \\
\quad(1 \text { st cycle) }\end{array}$} & Plot preparation & 5 January 2019 \\
\hline & & Mulch application ${ }^{2}$ & 14 January 2019 \\
\hline & & Planting & 16 January 2019 \\
\hline & & Harvest & 11 May 2019 \\
\hline & \multirow{4}{*}{$\begin{array}{l}\text { Irrigated Cabbage } \\
\text { (2nd cycle) }\end{array}$} & Tillage $^{1}$ & 6 October 2019 \\
\hline & & Mulch application $^{2}$ & 19 October 2019 \\
\hline & & Transplanting & 20 October 2019 \\
\hline & & Harvest & 25 February 2020 \\
\hline & \multirow{4}{*}{$\begin{array}{l}\text { Irrigated Potato } \\
\text { (3rd cycle) }\end{array}$} & Tillage $^{1}$ & 28 February 2020 \\
\hline & & Mulch application ${ }^{2}$ & 3 March 2020 \\
\hline & & Planting & 5 March 2020 \\
\hline & & Harvest & 30 June 2020 \\
\hline \multirow{19}{*}{ Affesa } & \multirow{5}{*}{$\begin{array}{l}\text { Irrigated Potato } \\
\text { (1st cycle) }\end{array}$} & Plot preparation & 5 February 2019 \\
\hline & & Mulch application ${ }^{2}$ & 10 February 2019 \\
\hline & & Planting & 11 February 2019 \\
\hline & & UREA $^{3}$ application & 13 March 2019 \\
\hline & & Harvest & 20 May 2019 \\
\hline & \multirow{5}{*}{$\begin{array}{l}\text { Irrigated Onion } \\
\quad \text { (2nd cycle) }\end{array}$} & Tillage $^{1}$ & 10 December 2019 \\
\hline & & Mulch application $^{2}$ & 14 December 2019 \\
\hline & & Planting & 15 December 2019 \\
\hline & & URAE $^{3}$ application & 26 January 2020 \\
\hline & & Harvest & 25 March 2020 \\
\hline & \multirow{9}{*}{ Rainfed Maize } & Plot preparation & 27 March 2019 \\
\hline & & Mulch application ${ }^{2}$ & 15 May 2019 \\
\hline & & Planting & 23 May 2019 \\
\hline & & $\mathrm{DAP}^{3}$ application & 23 May 2019 \\
\hline & & UREA $^{3}$ application & 14 June 2019 \\
\hline & & Diazinon $60 \%{ }^{4}$ application & 7 July 2019 \\
\hline & & Forage inter-cropping & 21 September 2019 \\
\hline & & Maize harvest & 18 October 2019 \\
\hline & & Forage harvest & 21 November 2019 \\
\hline
\end{tabular}

Note ${ }^{1}$ Only for CT plots; ${ }^{2}$ only for CA plots; ${ }^{3}$ Fertilizer; ${ }^{4}$ Pesticide.
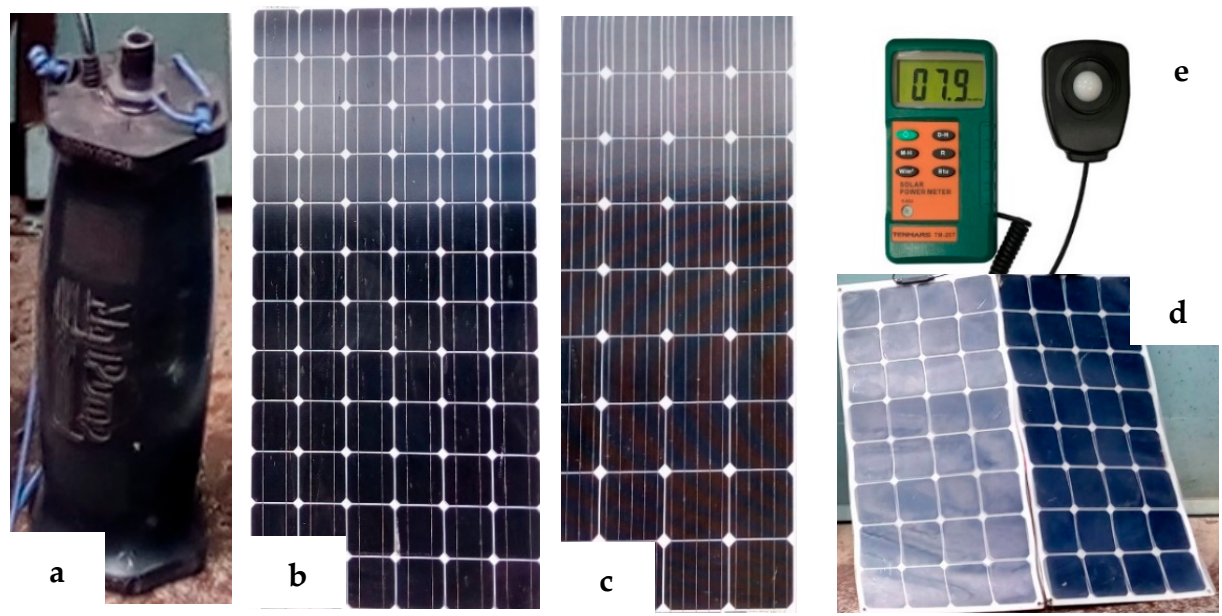

Figure 4. Pictures; (a) MajiPump, (b) $200 \mathrm{~W}$ rigid solar panel, (c) $150 \mathrm{~W}$ rigid solar panel, (d) $2 \times 100 \mathrm{~W}$ flexible solar panel, and (e) solar meter. The $200 \mathrm{~W}$ rigid and $2 \times 100 \mathrm{~W}$ flexible panels were connected in series with MP400 pumps, whereas the $150 \mathrm{~W}$ panel was connected with an MP200 pump. 
The MajiPumps were tested using the different panels for their discharge head and flow rate capacity. Digital Tenmars TM-207 (Figure 4e) solar power meter $\left(0.1 \mathrm{~W} / \mathrm{m}^{2}\right.$ resolution) was used to measure solar intensity. The MP400 and MP200 pumps were immersed in the water after a $\frac{3}{4}$ inch high-density polyethylene (HDPE) pipe was fitted and a digital stopwatch was used to record the time taken for a specific volume of water. The analog water meter was used to measure flow volume at different discharge head. A tape measure was used to measure water level depth (head) where the pump is installed. When the solar panel and pump setup, a connection cable was used to connect the pump with the panel and supply power. At this instant, where the pump starts to run, both the water meter and stopwatch start recording. The pump runs until the amount of water yield reaches $100 \mathrm{~L}$ and the flow rate was determined $(\mathrm{L} / \mathrm{S})$. The maximum discharge head and flow rate were considered as the capacity of the pumps (MP400 and MP200). At the experimental sites (Alefa and Affesa), groundwater depth from the surface was monitored throughout the year to compare it with the MajiPumps discharge head capacity and determine the applicability of pumps in the study area.

\subsection{Water and Crop Productivity Data Analysis}

Farmers could decide the irrigation interval and amount based on their field observation on soil moisture. Farmer's water application practice (i.e., application dates and amounts) were recorded from each plot after every irrigation based on the availability of water in the fixed water storage tanks $(1000 \mathrm{~L})$ for the dry season production. Crop yield (Y) was measured as weight during harvest separately for each soil and water management (i.e., CA, CT, and overhead and drip irrigation). Water productivity (WP), the amount of yield per unit volume of water [58], was computed as a quotient of crop yield and amount of water applied (irrigation and effective rainfall) as shown in Equation (2). The effects of management practices on irrigation water use, crop yield, and water productivity were analyzed using a paired t-test at a 5\% significance level. Besides, the variability of forage production among participant farmers due to effort and commitment was analyzed using the coefficient of variation.

$$
\left(W P=\frac{Y}{I+P e}\right)
$$

where $W P, Y, I, P e$ are water productivity $\left(\mathrm{kg} / \mathrm{m}^{3}\right)$, yield $(\mathrm{kg})$, irrigated water $\left(\mathrm{m}^{3}\right)$, and effective rainfall $\left(\mathrm{m}^{3}\right)$, respectively.

\section{Results}

\subsection{Soil Properties Across Experimental Plots}

Several soil physio-chemical properties were analyzed at various soil depths (i.e., 0-30 cm, 30-60 cm, and 60-90 cm) to check variability across experimental plots (Table 2). Gallardo [59] explained that variability of soil properties can be best described using the coefficient of variation (CV); high variability when the CV is greater than $91 \%$ and low variability if otherwise. Based on $\mathrm{CV}$ analysis, the variability of soil properties was low across experimental plots at both sites (i.e., Alefa and Affesa), satisfying precondition for paired management comparisons. The soil class in Alefa site is clay loam (0 to $30 \mathrm{~cm})$ and clay $(30$ to $90 \mathrm{~cm})$, whereas it is clay $(0$ to $60 \mathrm{~cm})$ and silt clay $(60$ to $90 \mathrm{~cm})$ in Affesa site. Soil salinity was generally low in the highlands of Ethiopia where the experimental sites are located [60]. 
Table 2. Mean value of soil physio-chemical properties across experimental plots for Alefa and Affesa.

\begin{tabular}{|c|c|c|c|c|c|c|c|c|c|c|}
\hline \multirow{3}{*}{ Site } & \multirow{3}{*}{ Soil Properties } & \multirow{3}{*}{ No. } & \multicolumn{8}{|c|}{ Soil Depth } \\
\hline & & & \multicolumn{4}{|c|}{$0-30 \mathrm{~cm}$} & \multicolumn{2}{|c|}{$30-60 \mathrm{~cm}$} & \multicolumn{2}{|c|}{$60-90 \mathrm{~cm}$} \\
\hline & & & Mean & Max. & Min. & $\mathrm{CV}$ & Mean & $\mathrm{CV}$ & Mean & $\mathrm{CV}$ \\
\hline \multirow{11}{*}{ Alefa } & $\mathrm{pH}$ & $\mathrm{H}_{2} \mathrm{O}$ & 5.7 & 6.4 & 5.1 & 9.7 & 5.7 & 3.9 & 5.2 & 2.3 \\
\hline & \multirow{3}{*}{ Texture } & $\%$ sand & 43.8 & 61 & 27 & 28.3 & 19.0 & 33.3 & 23.8 & 45.5 \\
\hline & & \% silt & 28.6 & 31 & 27 & 5.9 & 23.8 & 14.1 & 22.6 & 40.3 \\
\hline & & \% clay & 27.6 & 44 & 12 & 43.6 & 57.2 & 16.3 & 53.6 & 36.5 \\
\hline & OC & $\%$ & 3.1 & 4.5 & 2.1 & 29.2 & 1.7 & 22.6 & 1.5 & 37.2 \\
\hline & $\mathrm{OM}$ & $\%$ & 5.4 & 5.4 & 7.7 & 29.1 & 2.9 & 22.7 & 2.6 & 37.2 \\
\hline & $\mathrm{TN}$ & $\%$ & 0.3 & 0.4 & 0.2 & 30.2 & 0.1 & 21.4 & 0.1 & 39.5 \\
\hline & Av. P & ppm & 36.9 & 71.8 & 11.1 & 71.7 & 11.1 & 31.5 & 4.6 & 112 \\
\hline & Av. K & ppm & 127.0 & 163 & 100 & 18.4 & 96.3 & 28.0 & 83.0 & 43.7 \\
\hline & $\mathrm{FC}$ & $\%$ & 30.2 & 31 & 29 & 3.7 & 29.7 & 4.4 & 35.9 & 6.8 \\
\hline & PWP & $\%$ & 16.5 & 21.5 & 11.1 & 25.7 & 13.7 & 7.0 & 21.4 & 4.8 \\
\hline \multirow{11}{*}{ Affesa } & $\mathrm{pH}$ & $\mathrm{H}_{2} \mathrm{O}$ & 4.6 & 5 & 4.2 & 7.8 & 4.55 & 4.9 & 4.6 & 3 \\
\hline & \multirow{3}{*}{ Texture } & $\%$ sand & 19 & 22 & 14 & 18.2 & 19.5 & 30.6 & 13.0 & 19.9 \\
\hline & & \% silt & 35.5 & 50 & 26 & 31.0 & 18.5 & 29.8 & 20.0 & 21.6 \\
\hline & & \% clay & 45.5 & 55 & 36 & 19.5 & 62.0 & 7.4 & 67.0 & 9.9 \\
\hline & OC & $\%$ & 2.5 & 2.7 & 2.3 & 7.8 & 1.8 & 35.7 & 2.1 & 24.8 \\
\hline & $\mathrm{OM}$ & $\%$ & 4.3 & 4.6 & 3.9 & 7.8 & 3.1 & 35.9 & 3.6 & 25.0 \\
\hline & $\mathrm{TN}$ & $\%$ & 0.2 & 0.2 & 0.18 & 20.7 & 0.1 & 31.1 & 0.2 & 21.6 \\
\hline & Av. P & ppm & 8.6 & 13 & 3.6 & 44.1 & 3.7 & 11.5 & 4.7 & 25.5 \\
\hline & Av. K & ppm & 41.6 & 56 & 28.5 & 27.3 & 38.4 & 30.2 & 33.8 & 30.5 \\
\hline & $\mathrm{FC}$ & $\%$ & 27.6 & 30 & 27 & 1.5 & 27.6 & 1.0 & 26.8 & 3.4 \\
\hline & PWP & $\%$ & 17.2 & 18 & 16 & 3.7 & 16.9 & 2.1 & 17.0 & 4.3 \\
\hline
\end{tabular}

Note: CV, Max., Min., OC, OM, TN, Av. P, Av. K, FC, PWP are coefficient of variation, maximum, minimum, organic carbon, organic matter, total nitrogen, available phosphorous, available potassium, field capacity, and permanent wilting point, respectively. Maximum and minimum values of soil properties were provided for the topsoil $(0-30 \mathrm{~cm})$.

\subsection{MajiPumps Capacity and Groundwater Depth in the Study Area}

The MajiPumps (MP400 and MP200) discharge head and discharge relations of the different solar panels (i.e., $200 \mathrm{~W}$ flexible, $200 \mathrm{~W}$, and 150 rigid) best fitted $\left(\mathrm{R}^{2}>0.8\right)$ with the natural logarithmic function (Figure 5). The MajiPumps were tested at the various solar intensity in the study region ranging from $1026 \mathrm{~W} / \mathrm{m}^{2}$ to $1230 \mathrm{~W} / \mathrm{m}^{2}$. The maximum discharge heads for MP400 with 200W rigid panel (Figure 5a), MP400 with $200 \mathrm{~W}$ flexible panel (Figure 5b), and MP200 with rigid panel (Figure $5 \mathrm{c}$ ) were observed to be $18 \mathrm{~m}, 14 \mathrm{~m}$, and $10 \mathrm{~m}$, respectively. The minimum water yields capacity of the pumps from the shallow groundwater wells at the point of maximum discharge heads (i.e., $18 \mathrm{~m}, 14 \mathrm{~m}$, and $10 \mathrm{~m}$ ) were found $0.13 \mathrm{~L} / \mathrm{S}, 0.05 \mathrm{~L} / \mathrm{S}$, and $0.06 \mathrm{~L} / \mathrm{S}$, for MP400 with $200 \mathrm{~W}$ rigid panel, MP400 with $200 \mathrm{~W}$ flexible panel, and MP200 with $150 \mathrm{~W}$ rigid panels, respectively. The maximum pumping discharges for MP400 with 200 rigid panels, MP400 with $200 \mathrm{~W}$ flexible panel, and MP200 with $150 \mathrm{~W}$ rigid panel were found $0.41 \mathrm{~L} / \mathrm{S}, 0.25 \mathrm{~L} / \mathrm{S}$, and $0.37 \mathrm{~L} / \mathrm{S}$, respectively.

Groundwater depth at Alefa and Affesa sites were monitored (Figure 6) throughout the year to explore potentials for irrigation using the solar MajiPump water-lifting technology. Water levels were measured from the second week of March 2019 to the first week of August 2020 for Alefa and from the last week of February 2019 to the first week of July 2020. The depth of groundwater level in the shallow well ranges from $1.6 \mathrm{~m}$ (in October) to $9 \mathrm{~m}$ (last week of April) at Alefa site, whereas it ranges from $2 \mathrm{~m}$ (first week of August) to $12 \mathrm{~m}$ (first week of April) at Affesa site. 


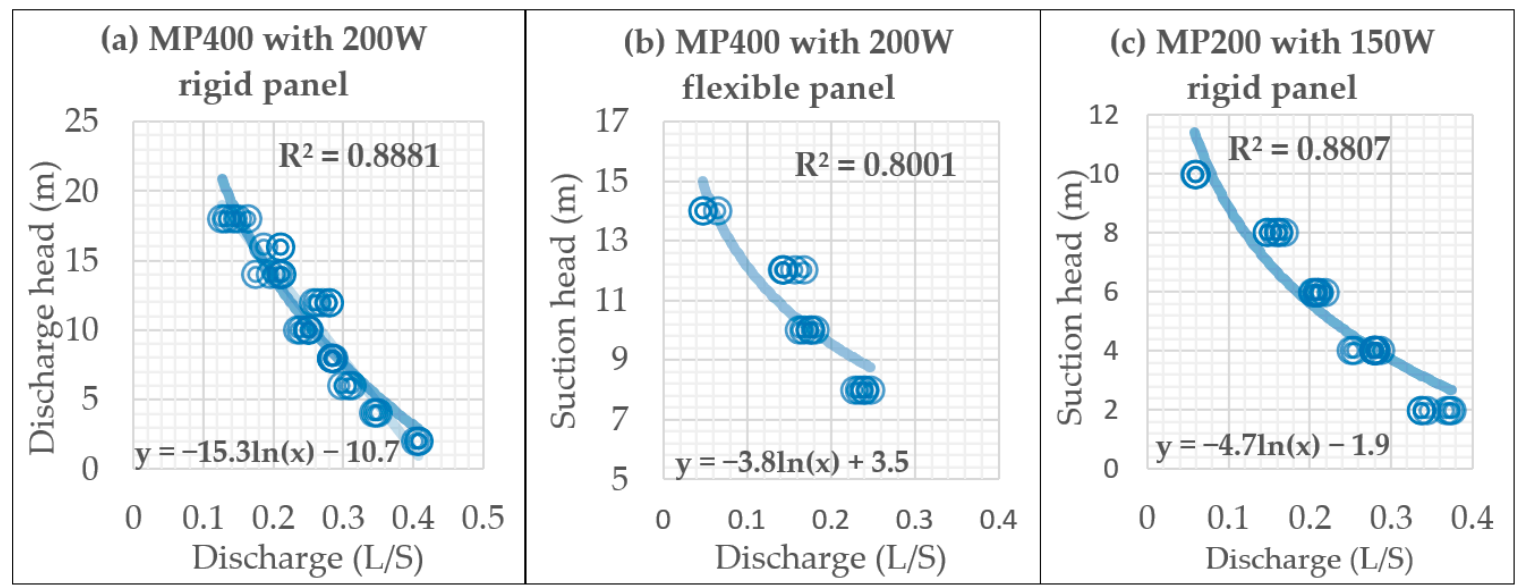

Figure 5. Discharge head and discharge curves of MajiPumps for solar intensity ranges in the study region (1026 to $\left.1230 \mathrm{~W} / \mathrm{m}^{2}\right)$.
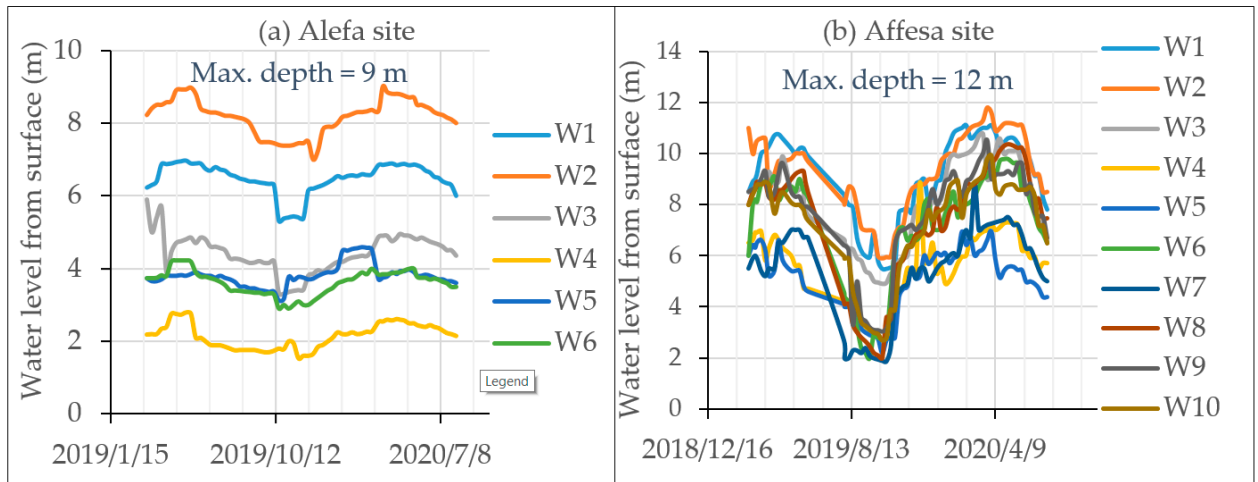

Figure 6. Groundwater depth from surface at Alefa (a) and Affesa (b) sites.

\subsection{Effects of Farming and IrrigationSystems on Crop Growth Characteristics}

A one-tailed paired t-test was conducted to analyze plant height for garlic, cabbage, potato, onion, and maize (Table 3). The mean plant height was significantly improved under CA for garlic and potato, whereas the improvements for cabbage and maize height was not statistically significant. The mean plant height of garlic and potato were improved under CA, respectively, by $17 \%$ and $7 \%$ when compared with the CT. Drip irrigation significantly improved potato height by $8 \%$ when compared with the overhead water application system, whereas the improvement of onion height was not statistically significant.

Similarly, a one-tailed paired t-test was used to analyze potato tuber diameter, cabbage head diameter, garlic, and onion bulb diameter under the different soil management practices and irrigation systems (Table 4). Both garlic bulb diameter and cabbage head diameter were significantly improved under CA when compared with CT, which were increased by $35 \%$ and $26 \%$, respectively, under CA. Potato tuber diameter was significantly improved under the drip water application when compared with the overhead water application system, whereas the improvement for the onion bulb diameter was not statistically significant. The mean potato tuber diameter was improved by $23 \%$ under drip irrigation when compared with under the overhead system. 
Table 3. Mean value of plant height under different tillage (CA versus CT) and water management (drip versus overhead water application) systems.

\begin{tabular}{|c|c|c|c|c|c|}
\hline \multirow{2}{*}{ Management } & \multirow{2}{*}{ Statistics } & \multicolumn{3}{|c|}{ Plant Height (cm) } & \multirow[b]{2}{*}{ Maize } \\
\hline & & Garlic & Cabbage & Potato & \\
\hline Sample size & $\mathbf{N}$ & 120 & 90 & 90 & 90 \\
\hline \multirow{3}{*}{ CA } & Mean & 44.8 & 30.6 & 44 & 293.4 \\
\hline & Max. & 55 & 56 & 52 & 327 \\
\hline & Min. & 13 & 12 & 12 & 118 \\
\hline \multirow{3}{*}{$\mathrm{CT}$} & Mean & 38.4 & 29.3 & 41.3 & 292.3 \\
\hline & Max. & 50 & 37 & 47 & 325 \\
\hline & Min. & 8 & 13 & 9 & 116 \\
\hline \multirow[t]{3}{*}{$\mathrm{CA} \mid \mathrm{CT}$} & $\mathrm{SEM} \pm$ & $1.95 \mid 2.2$ & $0.7 \mid 0.7$ & $3 \mid 2.3$ & $16.9 \mid 17.3$ \\
\hline & $p$-value & $0.0005^{* * *}$ & 0.3 & $0.02 * *$ & 0.19 \\
\hline & & Potato & Onion & & \\
\hline Sample size & $\mathrm{N}$ & 105 & 105 & & \\
\hline \multirow{3}{*}{ Drip } & Mean & 34.1 & 49 & & \\
\hline & Max. & 46.4 & 67 & & \\
\hline & Min. & 17.5 & 5 & & \\
\hline \multirow{3}{*}{ Overhead } & Mean & 31.7 & 48 & & \\
\hline & Max. & 43.9 & 65 & & \\
\hline & Min. & 15.9 & 4 & & \\
\hline \multirow[t]{2}{*}{ Drip | Overhead } & $\mathrm{SEM} \pm$ & $4.8 \mid 4.9$ & $0.63 \mid 0.93$ & & \\
\hline & $p$-value & $0.00003^{* * *}$ & 0.09 & & \\
\hline
\end{tabular}

Note: N, SEM, Max., Min., ${ }^{* *},{ }^{* * *}$ are sample size, standard error of the mean, maximum, minimum, and significance at $p<0.05$ and $p<0.001 \%$, respectively.

Table 4. Mean value of bulb, tuber, and cabbage head diameter different tillage (CA versus CT) and water management (drip versus overhead water application) systems.

\begin{tabular}{|c|c|c|c|}
\hline \multirow{2}{*}{ Management } & \multirow{2}{*}{ Statistics } & \multicolumn{2}{|c|}{ Diameter (cm) } \\
\hline & & Garlic Bulb & Cabbage Head \\
\hline Sample size & $\mathbf{N}$ & 120 & 90 \\
\hline \multirow{3}{*}{ CA } & Mean & 3.5 & 9.3 \\
\hline & Max. & 5 & 11.6 \\
\hline & Min. & 1.9 & 7.2 \\
\hline \multirow{3}{*}{$\mathrm{CT}$} & Mean & 2.6 & 7.4 \\
\hline & Max. & 4 & 9.5 \\
\hline & Min. & 1.5 & 5.6 \\
\hline \multirow[t]{3}{*}{$\mathrm{CA} \mid \mathrm{CT}$} & $\mathrm{SEM} \pm$ & $0.18 \mid 0.17$ & $0.6 \mid 0.5$ \\
\hline & $p$-value & $0.001^{* * *}$ & $0.0004^{* * *}$ \\
\hline & & Potato tuber & Onion bulb \\
\hline Sample size & $\mathrm{N}$ & 105 & 105 \\
\hline \multirow{3}{*}{ Drip } & Mean & 3.8 & 4.0 \\
\hline & Max. & 5.2 & 6 \\
\hline & Min. & 1.95 & 2 \\
\hline \multirow{3}{*}{ Overhead } & Mean & 3.1 & 3.8 \\
\hline & Max. & 5.34 & 6 \\
\hline & Min. & 1.9 & 2 \\
\hline \multirow[t]{2}{*}{ Drip I Overhead } & $\mathrm{SEM} \pm$ & $0.18 \mid 0.09$ & $0.13 \mid 0.26$ \\
\hline & $p$-value & $0.002 * *$ & 0.2 \\
\hline
\end{tabular}

Note: N, SEM, Max., Min. ${ }^{* *},{ }^{* * *}$ are sample size, standard error of the mean, maximum, minimum, and significance at $p<0.01$ and $p<0.001$, respectively. 


\subsection{Direct Effects of Farming and Irrigation Systems on Water Use and Crop Yield}

A one-tailed paired t-test was used to analyze the impacts of soil and water management practices on the amount of water applied (irrigation plus effective rainfall), Table 5. The mean water use was significantly reduced $(\alpha=5 \%)$ under CA for all vegetables (Table 5). The mean water uses of garlic, cabbage, and potato mean water uses were reduced, respectively, by $18 \%, 8 \%$, and $9 \%$ under CA when compared to CT. However, the water use difference was not statistically significant $(\alpha=5 \%)$ between drip and overhead water application systems, both under CA practice.

Table 5. The mean value of crops totals water uses under different tillage (CA versus CT) and water management (drip versus overhead water application) systems.

\begin{tabular}{|c|c|c|c|c|}
\hline \multirow{2}{*}{ Management } & \multirow{2}{*}{ Statistics } & \multicolumn{3}{|c|}{ Water Use (mm) } \\
\hline & & Garlic & Cabbage & Potato \\
\hline \multirow{5}{*}{ CA } & $\mathrm{N}$ & 8 & 6 & 6 \\
\hline & Mean & 316 & 380 & 294 \\
\hline & Max. & 425 & 497 & 304 \\
\hline & Min. & 267 & 294 & 281 \\
\hline & Mean & 386 & 414 & 323 \\
\hline \multirow[t]{2}{*}{ CT } & Max. & 435 & 301 & 331 \\
\hline & Min. & 308 & 549 & 313 \\
\hline \multirow[t]{5}{*}{$\mathrm{CA} \mid \mathrm{CT}$} & $\mathrm{SEM} \pm$ & $18.7 \mid 16.3$ & $33.4 \mid 38.7$ & $4.5 \mid 3.6$ \\
\hline & $p$-value & $0.0007^{* * *}$ & $0.0002^{* * *}$ & $0.0003^{* * * *}$ \\
\hline & & Potato & Onion & \\
\hline & $\mathrm{N}$ & 7 & 7 & \\
\hline & Mean & 341 & 247 & \\
\hline \multirow[t]{3}{*}{ Drip } & Max. & 374 & 265 & \\
\hline & Min. & 295 & 204 & \\
\hline & Mean & 350 & 246 & \\
\hline \multirow[t]{2}{*}{ Overhead } & Max. & 398 & 270 & \\
\hline & Min. & 304 & 207 & \\
\hline \multirow[t]{2}{*}{ Drip I Overhead } & $\mathrm{SEM} \pm$ & $10.3 \mid 11.7$ & $5.9 \mid 6.0$ & \\
\hline & $p$-value & 0.21 & 0.5 & \\
\hline
\end{tabular}

Note: N, SEM, Max., Min., ${ }^{* * *}$ are sample size, standard error of the mean, maximum, minimum, and significance at $p<0.001$, respectively.

Crop yields were significantly increased under CA and drip irrigation systems (Table 6) for all crops (i.e., irrigated vegetables and rainfed maize production). The mean crop yields of the garlic bulb, fresh cabbage, potato tuber, and maize grain were increased by $170 \%$, $42 \%, 43 \%$, and $15 \%$ under CA when compared with CT, respectively, though water applications were significantly reduced under CA practice. Similarly, the mean crop yields of potato tuber and onion bulb were significantly increased under the drip irrigation system when compared with the overhead water application using a hose, though both irrigation systems were under CA practice. Potato and onion yields were increased by $43 \%$ and $36 \%$, respectively, under drip water application when compared to overhead water application using a hose. On the other hand, farmers were able to harvest from about $5 \mathrm{tha}^{-1}$ to $12.5 \mathrm{t} \mathrm{ha}^{-1}$ of forage biomass beside $7.2 \mathrm{tha}^{-1}$ of maize production without using irrigation

\subsection{Effects of CA and Irrigation System on Water Productivity}

Water productivity was found significantly increased under CA and drip irrigation systems for all crops during both irrigated and dry season production (Table 7). The mean water productivity of garlic, cabbage, potato, and maize was increased, respectively, by $256 \%, 43 \%, 53 \%$, and $9 \%$ under CA when compared with CT. Similarly, water productivity of potato and onion was significantly increased under a drip irrigation system when compared with an overhead system, both irrigation systems were under CA practice. The mean water productivity of potato and onion was increased by $38 \%$ and $33 \%$ under, 
respectively, under the drip water application system when compared with overhead water application using a hose.

Table 6. The mean value of crop yields under different tillage (CA versus $\mathrm{CT}$ ) and water management (drip versus overhead water application) systems.

\begin{tabular}{|c|c|c|c|c|c|}
\hline \multirow{2}{*}{ Management } & \multirow{2}{*}{ Statistics } & \multicolumn{3}{|c|}{ Crop Yield (t ha-1) } & \multirow[b]{2}{*}{ Maize Grain } \\
\hline & & Garlic Bulb & Cabbage Fresh & Potato Tuber & \\
\hline Sample size & $\mathrm{N}$ & 8 & 6 & 6 & 6 \\
\hline \multirow{3}{*}{ CA } & Mean & 10 & 78 & 38.6 & 8.3 \\
\hline & Max. & 17 & 95 & 50 & 10 \\
\hline & Min. & 3.55 & 62.5 & 30 & 6.3 \\
\hline \multirow{3}{*}{$\mathrm{CT}$} & Mean & 3.7 & 55 & 27 & 7.2 \\
\hline & Max. & 6.5 & 72.5 & 35 & 9.5 \\
\hline & Min. & 1 & 45 & 20 & 5 \\
\hline \multirow[t]{3}{*}{ CAICT } & $\mathrm{SEM} \pm$ & $1.5 \mid 0.77$ & $4.5 \mid 4.3$ & $2.8 \mid 2.3$ & $0.54 \mid 0.63$ \\
\hline & $p$-value & $0.0003^{* * *}$ & $0.007^{* * *}$ & $0.00008^{* * *}$ & $0.001^{* * *}$ \\
\hline & & Potato Tuber & Onion Bulb & & \\
\hline Sample size & $\mathrm{N}$ & 7 & 7 & & \\
\hline \multirow{3}{*}{ Drip } & Mean & 38.6 & 9.1 & & \\
\hline & Max. & 43.9 & 11.2 & & \\
\hline & Min. & 21.9 & 6 & & \\
\hline \multirow{3}{*}{ Overhead } & Mean & 27 & 6.7 & & \\
\hline & Max. & 35.3 & 9 & & \\
\hline & Min. & 18 & 3.6 & & \\
\hline \multirow[t]{2}{*}{ Drip / Overhead } & $\mathrm{SEM} \pm$ & $3.5 \mid 2.1$ & $0.58 \mid 0.61$ & & \\
\hline & $p$-value & $0.016^{*}$ & $0.0001^{* * *}$ & & \\
\hline
\end{tabular}

Note: N, SEM, Max., Min., ${ }^{*}, * * *$ are sample size, standard error of the mean, maximum, minimum, and significance at $p<0.05$, and $p<0.001 \%$, respectively.

Table 7. Mean value of water productivity under different tillage (CA versus $\mathrm{CT}$ ) and water management (drip versus overhead water application) systems.

\begin{tabular}{cccccc}
\hline \multirow{2}{*}{ Management } & \multirow{2}{*}{ Statistics } & \multicolumn{4}{c}{ Water Productivity $\left(\mathbf{k g ~ m}^{-3}\right)$} \\
\cline { 3 - 6 } & & Garlic Bulb & Cabbage Fresh & Potato Tuber & Maize Grain \\
\hline \multirow{2}{*}{ Sample size } & $\mathrm{N}$ & 8 & 6 & 6 & 6 \\
\hline \multirow{2}{*}{ CA } & Mean & 3.2 & 20.4 & 13.3 & 1.2 \\
& Max. & 4.6 & 24.9 & 16.4 & 1.5 \\
& Min. & 1.3 & 16 & 10 & 0.9 \\
\hline \multirow{2}{*}{ CT } & Mean & 1 & 14.3 & 8.7 & 1.1 \\
& Max. & 1.7 & 20.8 & 10.6 & 1.5 \\
& Min. & 0.3 & 9.8 & 6 & 0.7 \\
\hline \multirow{2}{*}{ CAICT } & SEM \pm & $0.42 \mid 0.18$ & $1.6 \mid 1.8$ & $3.3 \mid 1.8$ & $0.08 \mid 0.09$ \\
& $p$-value & $0.0001^{* * *}$ & $0.003^{* *}$ & $0.002^{* *}$ & $0.001^{* * *}$ \\
\hline
\end{tabular}


Table 7. Cont.

\begin{tabular}{|c|c|c|c|c|c|}
\hline \multirow{2}{*}{ Management } & \multirow{2}{*}{ Statistics } & \multicolumn{3}{|c|}{ Water Productivity $\left(\mathrm{kg} \mathrm{m}^{-3}\right)$} & \multirow[b]{2}{*}{ Maize Grain } \\
\hline & & Garlic Bulb & Cabbage Fresh & Potato Tuber & \\
\hline & & Potato Tuber & Onion Bulb & & \\
\hline Sample size & $\mathrm{N}$ & 7 & 7 & & \\
\hline \multirow{3}{*}{ Drip } & Mean & 9.8 & 3.6 & & \\
\hline & Max. & 13.9 & 4.7 & & \\
\hline & Min. & 5.8 & 2.5 & & \\
\hline \multirow{3}{*}{ Overhead } & Mean & 7.1 & 2.7 & & \\
\hline & Max. & 9.5 & 3.9 & & \\
\hline & Min. & 3.8 & 1.6 & & \\
\hline \multirow[t]{2}{*}{ Drip | Overhead } & $\mathrm{SEM} \pm$ & $3.5 \mid 2.1$ & $0.58 \mid 0.61$ & & \\
\hline & $p$-value & $0.016^{*}$ & $0.0001^{* * *}$ & & \\
\hline
\end{tabular}

Note: N, SEM, Max., Min., ${ }^{*}{ }^{* *},{ }^{* * *}$ are sample size, standard error of the mean, maximum, minimum, and significance at $p<0.05, p<0.01$ and $p<0.001$, respectively.

\section{Discussion}

\subsection{Evaluation of Solar MajiPumps}

On the specification of the MajiPumps, MP400 and MP200 would lift water up to $25 \mathrm{~m}$ (using $160 \mathrm{~W} 24 \mathrm{VDC}$ solar panel) and $10 \mathrm{~m}$ (using $80 \mathrm{~W} 12$ VDC solar panel), respectively, both having $34 \mathrm{~L} / \mathrm{min}$ open flow rate. During our field experiment, we observed that MP400 and MP200 pumps would lift water to a maximum of $18 \mathrm{~m}$ (using $200 \mathrm{~W} 24$ VDC solar panel) and $10 \mathrm{~m}$ (using $150 \mathrm{~W} 12 \mathrm{VDS}$ solar panels). The pipe maximum flow (3/4 inch in size) was found $24.6 \mathrm{~L} / \mathrm{min}$ for MP400 with $200 \mathrm{~W}$ rigid panel and $22.4 \mathrm{~L} / \mathrm{min}$ with a $150 \mathrm{~W}$ rigid panel. Various factors including solar intensity, panel types, and surrounding temperature could affect pump discharge head and discharge.

The minimum discharges from the shallow groundwater wells at the point of maximum discharge heads (i.e., $18 \mathrm{~m}, 14 \mathrm{~m}$, and $10 \mathrm{~m}$ ) were $7.8 \mathrm{~L} / \mathrm{min}, 3 \mathrm{~L} / \mathrm{min}$, and $23.6 \mathrm{~L} / \mathrm{min}$, for MP400 with $200 \mathrm{~W}$ rigid panel, MP400 with $200 \mathrm{~W}$ flexible panel, and MP200 with 150 $\mathrm{W}$ rigid panel, respectively. This minimum pump discharges could fill the $1000 \mathrm{~L}$ water storage tanks that farmers used for this experiment in $2.1 \mathrm{hr} ., 5.6 \mathrm{hr}$., and $4.6 \mathrm{hr}$., respectively. When the solar MajiPumps (i.e., MP400 with $200 \mathrm{~W}$ rigid panel, MP400 with $200 \mathrm{~W}$ flexible panel and MP200 with $150 \mathrm{~W}$ rigid panel) provides the maximum water yield capacity (i.e., $24.61 \mathrm{~L} / \mathrm{min}, 15 \mathrm{~L} / \mathrm{min}$, and $22.2 \mathrm{~L} / \mathrm{min}$ ), they could fill the $1000 \mathrm{~L}$ water storage tanks in $0.68 \mathrm{hr} ., 1.11 \mathrm{hr}$, and $0.75 \mathrm{hr}$., respectively. Considering 8-h effective solar intensity in a day, MP400 and MP200 pumps would lift a maximum of about 11,764 L/day and 10,666 L/day, respectively. This would help to provide irrigation between half and one hectare of land depending on crop types, farming systems, water application systems, and cropping season.

\subsection{Effects of CA on Water Productivity, and Crop Yields}

The water-saving capacity of CA was found significantly higher when compared to CT for the various irrigated vegetables and rainfed maize production. This was mainly due to a reduction of water loss from soil evaporation associated with the grass mulch cover in CA. Consequently, soil moisture would be maintained and available for crop use in the CA practice. Assefa et al. [28] found up to $49 \%$ reduction of evapotranspiration and up to $40 \%$ increment of soil moisture in CA practice for various vegetables, supporting the claim that reduction of water loss is mainly from reduced soil evaporation. Significant improvement of water productivity associated with CA practice was observed in the Ethiopian highlands $[13,27,28]$. CA was tested with drip irrigation previously $[11,16,22$, 25-28] showed a significant increase in water productivity. Similarly, in our study CA under both a drip irrigation system and overhead irrigation significantly increased water 
productivity. Thus, farmers who could not afford to buy a drip irrigation system would still get a significant water-saving benefit from the use of $\mathrm{CA}$, even with overhead irrigation.

Crop yield was found significantly higher in CA when compared to CT for the various irrigated vegetables and rainfed maize production. This was mainly due to an improvement in soil quality (nutrients) and water use efficiency in CA. Assefa, Jha, Reyes, Worqlul, Doro, and Tilahun [29] found more than $6 \%$ and $4 \%$ increment of soil organic $\mathrm{C}$ and total $\mathrm{N}$, respectively, under CA when compared with CT. Besides, CA decreased nutrient loss due to either runoff or percolation. Belay et al. [26] found a significant decrease of $\mathrm{NO}_{3}-\mathrm{N}$ (up to $44 \%$ ) and $\mathrm{PO}_{4}-\mathrm{P}$ (up to $50 \%$ ) in runoff and leachate under CA as compared to CT. This provides more readily available nutrients in CA for plant growth, leading to improved crop yields. Crop yield improvements in CA for this study (15-170\%) were found to be consistent with Assefa et al. [11] and Belay et al. [26], which showed 9\% to more than $100 \%$ yield improvements in CA with the drip irrigation system. This indicates, CA would still provide a significant improvement of soil quality and crop yield regardless of the irrigation practice (overhead or drip system).

\subsection{Effects of Drip Irrigation on Water Productivity and Crop Yield}

A significant water saving was observed under the drip system ( $38 \%$ for potato and $33 \%$ for onion), mainly due to the capability of the drip system in delivering water uniformly to the root of crops and minimizing water losses. Drip irrigation systems reduce water application to open ground or soil spaces that are not directly used by crops, which would rather facilitate weed growth. The result suggests that the combined use of drip irrigation and CA provides a significant water use efficiency as compared to the combination of CA and overhead irrigation. Assefa et al. [16] found nearly a threefold water saving capacity when combined with CA as compared to overhead irrigation with the tilled system. This will help minimize the overexploitation of shallow groundwater wells and maximize irrigated crop production. A similar result was reported by Kigalu, et al. [61] which found a quadratic response of water productivity for the drip system as compared to overhead irrigation in Tanzania.

The effect of the drip irrigation system was significant in improving crop productivity as compared to overhead irrigation. Potato and onion yield was increased by $43 \%$ and $36 \%$, respectively under drip irrigation. Dawit, et al. [62] reported similar results, improved crop yields for drip irrigation in the eastern part of Ethiopia. The uniform water application and minimum soil nutrient loss associated with the drip system would be the main reason for improved crop yield. Fandika, et al. [63] result indicated a higher tomato yield response associated with the uniform water application in the drip system. Whereas, Elhindi, et al. [64] and Mirjat, et al. [65] observed minimum loss of soil minerals, and fertilizers when using drip irrigation.

\subsection{Comparison of MajiPump with Previous Pulley Studies on Water Productivity}

Water productivity was significantly improved under MajiPump water-lifting system when compared with a pulley system $[11,22,29]$ for the same crop types (Figure 7 ). The water productivity values of garlic, onion, and cabbage under the MajiPump with CA were $3.2 \mathrm{~kg} \mathrm{~m}^{-3}, 9 \mathrm{~kg} \mathrm{~m}^{-3}$, and $20 \mathrm{~kg} \mathrm{~m}^{-3}$, respectively, while the corresponding values were $1.1 \mathrm{~kg} \mathrm{~m}^{-3}, 2.6 \mathrm{~kg} \mathrm{~m}^{-3}$, and $9.2 \mathrm{~kg} \mathrm{~m}^{-3}$ for the pulley system with CA (i.e., $190 \%, 246 \%$, and $117 \%$ improvements, respectively). Besides, the MajiPump showed a significant water productivity improvement in the conventional tilled (CT) system. The water productivity of garlic, onion, and cabbage under MajiPump with CT was $1 \mathrm{~kg} \mathrm{~m}^{-3}, 6.7 \mathrm{~kg} \mathrm{~m}^{-3}$, and 14.4 $\mathrm{kg} \mathrm{m}^{-3}$, respectively, and $0.6 \mathrm{~kg} \mathrm{~m}^{-3}, 0.2 \mathrm{~kg} \mathrm{~m}^{-3}$, and $6.9 \mathrm{~kg} \mathrm{~m}^{-3}$ under the pulley with CT system (i.e., $67 \%$ to $325 \%$ higher than the pulley with CT system). Moreover, the water productivity under the MajiPump with CT was higher than the pulley system with CA. The water productivity under the MajiPump with CT was $6.7 \mathrm{~kg} \mathrm{~m}^{-3}$ and $14.4 \mathrm{~kg} \mathrm{~m}^{-3}$, while it was $2.6 \mathrm{~kg} \mathrm{~m}^{-3}$ and $9.2 \mathrm{~kg} \mathrm{~m}^{-3}$ under the pulley system with CA, respectively, for onion and cabbage vegetables (i.e., $158 \%$ and $56 \%$ improvements, respectively). 


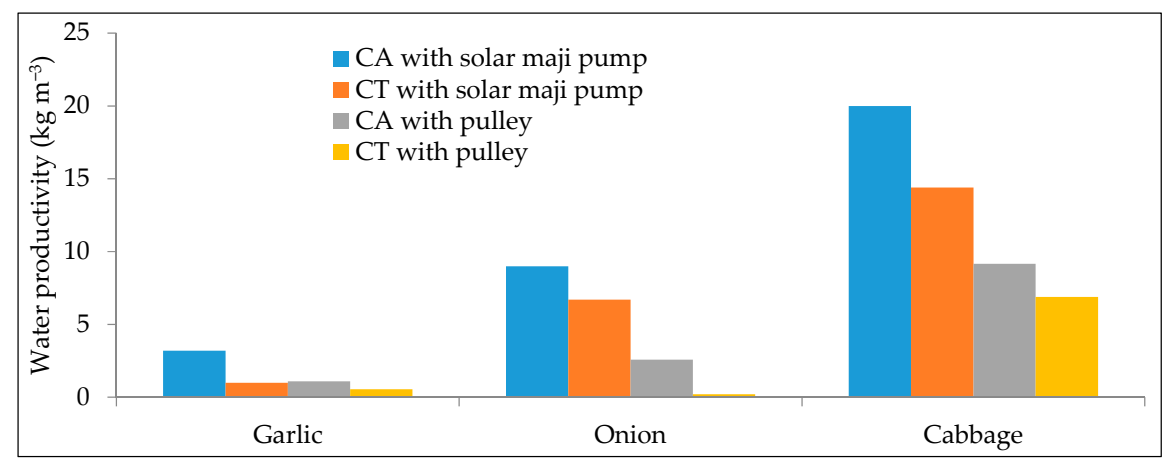

Figure 7. Comparison of MajiPump and pulley system on water productivity.

In general, the highest water productivity benefit could be gained through the combined use of MajiPump with CA practice. The highest water productivity in the MajiPump system was attributed to its additional advantage to increasing labor productivity. Farmers in the study area explained that water-lifting using the MajiPump took 5 to 10 min while a pulley system took 1.5 to $2 \mathrm{~h}$ to fill a $1.5 \mathrm{~m}$ height elevated $500 \mathrm{~L}$ water storage tank. Besides, filling a water storage tank with the pulley system requires two persons at a time when the labor time in the MajiPump system is only to connect the pump and solar panel. The minimum labor demand in using the MajiPump initiated smallholder farmers to provide enough irrigation water for vegetables, and thus increasing their water and labor productivity.

\section{Summary and Conclusions}

This research showed the potential benefits of the solar-powered water-lifting system (MajiPump) and CA technologies on water productivity and crop yields under on-farm conditions of smallholder farmers in Ethiopia. The capacity of two MajiPumps used in this study (MP400 and MP200) were found to extract water up to a maximum depth of $10 \mathrm{~m}$ using MP200 with $150 \mathrm{~W}$ rigid panel, $14 \mathrm{~m}$ using MP400 with $200 \mathrm{~W}$ flexible panel, and to $18 \mathrm{~m}$ using MP400 with $200 \mathrm{~W}$ rigid panel from shallow groundwater wells. The corresponding flow rate discharge capacity for these pumps and panel sizes were in the range of $7.8 \mathrm{~L} / \mathrm{min}$ to $24.6 \mathrm{~L} / \mathrm{min}, 3 \mathrm{~L} / \mathrm{min}$ to $15 \mathrm{~L} / \mathrm{min}$, and $3.6 \mathrm{~L} / \mathrm{min}$, to $22.2 \mathrm{~L} / \mathrm{min}$, respectively.

Water and crop productivity were significantly increased under the CA farming system when compared with CT, both using farmers' common overhead irrigation (hose system). Water productivity was improved by $9 \%$ to $256 \%$, and crop productivity was improved by $15 \%$ to $170 \%$ depending on the types of crops, and seasons of production (i.e., dry irrigated and rainfed). This shows the CA farming system has increased significant benefits (watersaving and crop yield increment) to farmers even using traditional overhead irrigation. However, the use of drip irrigation with the CA system further improved water and crop productivity as compared to the combination of the CA system with overhead irrigation. Besides, a significant increase in water productivity was observed in the combined use of MajiPump and CA when compared with the pulley water-lifting system. We conclude that the solar MajiPump with CA and drip irrigation is a promising approach to expand small-scale irrigation that can improve some key vegetable and grain crops of smallholder farmers in Ethiopia [7].

Author Contributions: T.T.A. contributed to the experimental design, data analysis and interpretation, and drafted the manuscript; T.F.A. contributed to the experimental design, data acquisition and analysis; A.Y.Y. contributed to experimental design, data collection and analysis; S.A.B. contributed to the data analysis and interpretation, revised the manuscript; Y.M.D. contributed to data collection and revising the manuscript; S.T.H. contributed to data collection and revising the manuscript, S.A.T. contributed to the data analysis and revising the manuscript; M.R.R. contributed to revising the 
manuscript; P.V.V.P. contributed to revising the manuscript. All authors have read and agreed to the published version of the manuscript.

Funding: This research was funded by the Appropriate Scale Mechanization Consortium of Feed the Future Innovation Lab for Collaborative Research on Sustainable Intensification (Cooperative Agreement No. AID-OAA-L-14-00006, Kansas State University) funded by United States Agency for International Development (USAID). The opinions expressed herein are those of the author(s) and do not necessarily reflect the views of the USAID or Kansas State University.

Data Availability Statement: The data presented in this study are available on request from the corresponding author.

Acknowledgments: We would like to acknowledge the Ethiopian National Meteorological Agency (ENMA) for providing quality data for this research. Contribution no. 21-122-J from Kansas Agricultural Experiment Station.

Conflicts of Interest: The authors declare no conflict of interest.

\section{References}

1. Diao, X.; Nin Pratt, A. Growth options and poverty reduction in Ethiopia-An economy-wide model analysis. Food Policy 2007, 32, 205-228. [CrossRef]

2. Weldearegawi, B.; Ashebir, Y.; Gebeye, E.; Gebregziabiher, T.; Yohannes, M.; Mussa, S.; Berhe, H.; Abebe, Z. Emerging chronic non-communicable diseases in rural communities of Northern Ethiopia: Evidence using population-based verbal au-topsy method in Kilite Awlaelo surveillance site. Health Policy Plan. 2013, 28, 891-898. [CrossRef] [PubMed]

3. Belachew, T.; Hadley, C.; Lindstrom, D.; Mariam, A.G.; Lachat, C.; Kolsteren, P. Food insecurity, school absenteeism and educational attainment of adolescents in Jimma Zone Southwest Ethiopia: A longitudinal study. Nutr. J. 2011, 10, 29. [CrossRef] [PubMed]

4. Awulachew, S.B.; Yilma, A.D.; Loulseged, M.; Loiskandl, W.; Ayana, M.; Alamirew, T. Water Resources and Irrigation Development in Ethiopia; IWMI: Colombo, Siri Lanka, 2007; Volume 123.

5. Tesfaye, A.; Bogale, A.; Namara, R.E.; Bacha, D. The impact of small-scale irrigation on household food security: The case of Filtino and Godino irrigation schemes in Ethiopia. Irrig. Drain. Syst. 2008, 22, 145-158. [CrossRef]

6. Haile, G.G.; Kasa, A.K. Irrigation in Ethiopia: A review. Acad. J. Agric. Res. 2015, 3, $264-269$.

7. Aseyehegu, K.; Yirga, C.; Rajan, S. Effect of Small-Scale Irrigation on the Income of Rural Farm Households: The Case of Laelay Maichew District, Central Tigray, Ethiopia. J. Stored Prod. Postharvest Res. 2011, 2, 208-215. [CrossRef]

8. Mengistie, D.; Asmamaw, D.K. Assessment of the Impact of Small-Scale Irrigation on Household Livelihood Improvement at Gubalafto District, North Wollo, Ethiopia. Agriculture 2016, 6, 27. [CrossRef]

9. Kuma, A.N.Y.; Alemu, A.A.T.; Nigussie, A.; Adisu, A.; Desalegn, K. Onion Production for Income Generation in Small Scale Irrigation Users Agropastoral Households of Ethiopia. J. Hortic. 2015, 2, 1-5. [CrossRef]

10. Gebrehiwot, N.T.; Mesfin, K.A.; Nyssen, J. Small-scale irrigation: The driver for promoting agricultural production and food security (the case of Tigray Regional State, Northern Ethiopia). Irrig. Drain. Syst. Eng. 2015, 4, 1000141. [CrossRef]

11. Assefa, T.; Jha, M.; Reyes, M.; Tilahun, S.; Worqlul, A.W. Experimental evaluation of conservation agriculture with drip irri-gation for water productivity in Sub-Saharan Africa. Water 2019, 11, 530. [CrossRef]

12. Berg, M.V.D.; Ruben, R. Small-Scale irrigation and income distribution in Ethiopia. J. Dev. Stud. 2006, 42, 868-880. [CrossRef]

13. Xie, H.; You, L.; Dile, Y.T.; Worqlul, A.W.; Bizimana, J.-C.; Srinivasan, R.; Richardson, J.W.; Gerik, T.; Clark, N. Mapping development potential of dry-season small-scale irrigation in Sub-Saharan African countries under joint biophysical and economic constraints-An agent-based modeling approach with an application to Ethiopia. Agric. Syst. 2021, 186, 102987. [CrossRef]

14. You, L.; Ringler, C.; Wood-Sichra, U.; Robertson, R.; Wood, S.; Zhu, T.; Nelson, G.; Guo, Z.; Sun, Y. What is the irrigation potential for Africa? A combined biophysical and socioeconomic approach. Food Policy 2011, 36, 770-782. [CrossRef]

15. Worqlul, A.W.; Jeong, J.; Dile, Y.T.; Osorio, J.; Schmitter, P.; Gerik, T.; Srinivasan, R.; Clark, N. Assessing potential land suita-ble for surface irrigation using groundwater in Ethiopia. Appl. Geogr. 2017, 85, 1-13. [CrossRef]

16. Assefa, T.; Jha, M.K.; Worqlul, A.W.; Reyes, M.R.; Tilahun, S.A. Scaling-Up Conservation Agriculture Production System with Drip Irrigation by Integrating MCE Technique and the APEX Model. Water 2019, 11, 2007. [CrossRef]

17. Awulachew, S.B. Irrigation potential in Ethiopia: Constraints and opportunities for enhancing the system. Gates Open Re-search 2019, 3. [CrossRef]

18. Worqlul, A.W.; Collick, A.S.; Rossiter, D.G.; Langan, S.; Steenhuis, T.S. Assessment of surface water irrigation potential in the Ethiopian highlands: The Lake Tana Basin. Catena 2015, 129, 76-85. [CrossRef]

19. Bacha, D.; Namara, R.E.; Bogale, A.; Tesfaye, A. Impact of small-scale irrigation on household poverty: Empirical evidence from the Ambo district in Ethiopia. Irrig. Drain. 2011, 60, 1-10. [CrossRef]

20. Derib, S.D.; Descheemaeker, K.; Haileslassie, A.; Amede, T. Irrigation water productivity as affected by water management in a small-scale irrigation scheme in the blue nile basin, ethiopia. Exp. Agric. 2011, 47, 39-55. [CrossRef] 
21. Theis, S.; Lefore, N.; Meinzen-Dick, R.; Bryan, E. What happens after technology adoption? Gendered aspects of small-scale irrigation technologies in Ethiopia, Ghana, and Tanzania. Agric. Hum. Values 2018, 35, 671-684. [CrossRef]

22. Yimam, A.Y.; Assefa, T.T.; Adane, N.F.; Tilahun, S.A.; Jha, M.K.; Reyes, M.R. Experimental Evaluation for the Impacts of Conservation Agriculture with Drip Irrigation on Crop Coefficient and Soil Properties in the Sub-Humid Ethiopian Highlands. Water 2020, 12, 947. [CrossRef]

23. Evans, A.E.; Giordano, M.; Clayton, T. Investing in Agricultural Water Management to Benefit Smallholder Farmers in Ethio-pia; AgWater Solutions Project Country Synthesis Report; IWMI: Colombo, Siri Lanka, 2012; Volume 152.

24. Namara, R.E.; Hope, L.; Sarpong, E.O.; De Fraiture, C.; Owusu, D. Adoption patterns and constraints pertaining to small-scale water lifting technologies in Ghana. Agric. Water Manag. 2014, 131, 194-203. [CrossRef]

25. Belay, S.A.; Schmitter, P.; Worqlul, A.W.; Steenhuis, T.S.; Reyes, M.R.; Tilahun, S.A. Conservation Agriculture Saves Irrigation Water in the Dry Monsoon Phase in the Ethiopian Highlands. Water 2019, 11, 2103. [CrossRef]

26. Belay, S.A.; Assefa, T.T.; Prasad, P.V.V.; Schmitter, P.; Worqlul, A.W.; Steenhuis, T.S.; Reyes, M.R.; Tilahun, S.A. The Response of Water and Nutrient Dynamics and of Crop Yield to Conservation Agriculture in the Ethiopian Highlands. Sustainability 2020, 12, 5989. [CrossRef]

27. Assefa, T.T. Experimental and Modeling Evaluation of Conservation Agriculture with Drip Irrigation for Small-scale Agri-culture in Sub-Saharan Africa. Ph.D. Thesis, North Carolina Agricultural and Technical State University, Greensboro, NC, USA, 2018.

28. Assefa, T.T.; Jha, M.K.; Reyes, M.R.; Worqlul, A.W. Modeling the Impacts of Conservation Agriculture with a Drip Irrigation System on the Hydrology and Water Management in Sub-Saharan Africa. Sustainability 2018, 10, 4763. [CrossRef]

29. Assefa, T.; Jha, M.; Reyes, M.; Worqlul, A.; Doro, L.; Tilahun, S. Conservation agriculture with drip irrigation: Effects on soil quality and crop yield in sub-Saharan Africa. J. Soil Water Conserv. 2020, 75, 209-217. [CrossRef]

30. Heumesser, C.; Fuss, S.; Szolgayová, J.; Strauss, F.; Schmid, E. Investment in irrigation systems under precipitation uncer-tainty. Water Resour. Manag. 2012, 26, 3113-3137. [CrossRef]

31. Burney, J.; Woltering, L.; Burke, M.; Naylor, R.; Pasternak, D. Solar-powered drip irrigation enhances food security in the Sudano-Sahel. Proc. Natl. Acad. Sci. USA 2010, 107, 1848-1853. [CrossRef]

32. Gowing, J.; Walker, D.; Parkin, G.; Forsythe, N.; Haile, A.T.; Ayenew, D.A.; Alamirew, D. Can shallow groundwater sustain small-scale irrigated agriculture in sub-Saharan Africa? Evidence from N-W Ethiopia. Groundw. Sustain. Dev. 2020, 10, 100290. [CrossRef]

33. Siebert, S.; Burke, J.; Faures, J.-M.; Frenken, K.; Hoogeveen, J.; Döll, P.; Portmann, F.T. Groundwater use for irrigation-A global inventory. Hydrol. Earth Syst. Sci. 2010, 14, 1863-1880. [CrossRef]

34. Nigussie, L.; Lefore, N.; Schmitter, P.; Nicol, A. Gender and Water Technologies: Water Lifting for Irrigation and Multiple Purposes in Ethiopia; International Livestock Research Institute (ILRI); East Africa and Nile Basin Office: Addis Ababa, Ethiopia, 2017.

35. Gray, C.; Mueller, V. Drought and Population Mobility in Rural Ethiopia. World Dev. 2012, 40, 134-145. [CrossRef] [PubMed]

36. Biswas, S.; Iqbal, M.T. Dynamic Modelling of a Solar Water Pumping System with Energy Storage. J. Sol. Energy 2018, 2018, 1-12. [CrossRef]

37. Kelley, L.C.; Gilbertson, E.; Sheikh, A.; Eppinger, S.D.; Dubowsky, S. On the feasibility of solar-powered irrigation. Renew. Sustain. Energy Rev. 2010, 14, 2669-2682. [CrossRef]

38. Gupta, E. The impact of solar water pumps on energy-water-food nexus: Evidence from Rajasthan, India. Energy Policy 2019, 129, 598-609. [CrossRef]

39. Chandel, S.; Naik, M.N.; Chandel, R. Review of solar photovoltaic water pumping system technology for irrigation and community drinking water supplies. Renew. Sustain. Energy Rev. 2015, 49, 1084-1099. [CrossRef]

40. Foley, G. Photovoltaic Applications in Rural Areas of the Developing World; World Bank: Washington, DC, USA, 1995 ; Volume 304.

41. Beriso, B.S. Prevalence of protein-energy malnutrition in children under five years of age admitted to pediatric wards at Asella Referral and Teaching Hospital, Arsi Zone, Oromiya, Ethiopia. East Afr. J. Sci. 2019, 13, 81-88.

42. Belay, M.; Bewket, W. Traditional Irrigation and Water Management Practices in Highland Ethiopia: Case Study IN Dangila Woreda. Irrig. Drain. 2013, 62, 435-448. [CrossRef]

43. Lemma, T.; Sehai, E.; Hoekstra, D. Status and Capacity of Farmer Training Centers (FTCs) in the Improving Productivity and Market Success (IPMS) Pilot Learning Woredas (PLWs); International Livestock Research Institute (ILRI): Addis Ababa, Ethiopia, 2011.

44. Walker, D.; Parkin, G.; Schmitter, P.; Gowing, J.; Tilahun, S.A.; Haile, A.T.; Yimam, A.Y. Insights from a multi-method re-charge estimation comparison study. Groundwater 2019, 57, 245-258. [CrossRef] [PubMed]

45. Abay, A. Market Chain Analysis of Red Pepper: The Case of Bure Woreda, West Gojjam Zone, Amhara National Regional State, Ethiopia; Haramaya University: Harar Haramaya, Ethiopia, 2010.

46. Eng, J. Sample Size Estimation: How Many Individuals Should Be Studied? Radiology 2003, 227, 309-313. [CrossRef] [PubMed]

47. De Winter, J.C. Using the Student's t-test with extremely small sample sizes. Pract. Assess. Res. Eval. 2013, 18, 10.

48. Assefa, T.; Jha, M.; Reyes, M.; Srinivasan, R.; Worqlul, A.W. Assessment of suitable areas for home gardens for irrigation po-tential, water availability, and water-lifting technologies. Water 2018, 10, 495. [CrossRef]

49. Iwama, K. Physiology of the Potato: New Insights into Root System and Repercussions for Crop Management. Potato Res. 2008, 51, 333-353. [CrossRef]

50. Gao, Y.; Duan, A.; Qiu, X.; Liu, Z.; Sun, J.; Zhang, J.; Wang, H. Distribution of roots and root length density in a maize/soybean strip intercropping system. Agric. Water Manag. 2010, 98, 199-212. [CrossRef] 
51. Westerveld, S.M.; McKeown, A.W.; McDonald, M.R. Distribution of nitrogen uptake, fibrous roots and nitrogen in the soil profile for fresh-market and processing carrot cultivars. Can. J. Plant Sci. 2006, 86, 1227-1237. [CrossRef]

52. Hsu, S.-L.; Hung, J.; Wallace, A. Soil pH Variation Within a Soil. I. pH Variation in Soil Pores Observed in a Column-Leaching Method. Commun. Soil Sci. Plant Anal. 2004, 35, 319-329. [CrossRef]

53. Tesema, M.; Schmitter, P.; Nakawuka, P.; Tilahun, S.A.; Steenhuis, T.; Langan, S. Evaluating Irrigation Technologies to Im-prove Crop and Water Productivity of Onion in Dangishta Watershed During the Dry Monsoon Phase. In Proceedings of the Fourth International Conference on the Advancement of Science and Technology in Civil and Water Resources Engineering, Bahir Dar, Ethiopia, 13-29 November 2019.

54. Zotarelli, L.; Dukes, M.D.; Romero, C.C.; Migliaccio, K.W.; Morgan, K.T. Step by Step Calculation of the Penman-Monteith Evapotranspiration (FAO-56 Method); Institute of Food and Agricultural Sciences, University of Florida: Gainesville, FL, USA, 2010.

55. Burney, J.; Naylor, R.L.; Postel, S.L. The case for distributed irrigation as a development priority in sub-Saharan Africa. Proc. Natl. Acad. Sci. USA 2013, 110, 12513-12517. [CrossRef]

56. Water Requirements for Irrigation and the Environment; Springer Science and Business Media LLC: Berlin, Germany, 2009.

57. Allen, R.G.; Pereira, L.S.; Raes, D.; Smith, M. Crop evapotranspiration-Guidelines for computing crop water requirements-FAO Irrigation and drainage paper 56. FAO Rome 1998, 300, D05109.

58. Ali, M.; Talukder, M. Increasing water productivity in crop production-A synthesis. Agric. Water Manag. 2008, 95, 1201-1213. [CrossRef]

59. Gallardo, A. Spatial Variability of Soil Properties in a Floodplain Forest in Northwest Spain. Ecosystems 2003, 6, 564-576. [CrossRef]

60. Aredehey, G.; Libsekal, H.; Brhane, M.; Welde, K.; Giday, A.; Moral, M.T. Top-soil salinity mapping using geostatistical approach in the agricultural landscape of Timuga irrigation scheme, South Tigray, Ethiopia. Cogent Food Agric. 2018, 4, 1514959. [CrossRef]

61. Kigalu, J.M.; Kimambo, E.I.; Msite, I.; Gembe, M. Drip irrigation of tea (Camellia sinensis L.): 1. Yield and crop water produc-tivity responses to irrigation. Agric. Water Manag. 2008, 95, 1253-1260. [CrossRef]

62. Dawit, M.; Dinka, M.O.; Leta, O.T. Implications of Adopting Drip Irrigation System on Crop Yield and Gender-Sensitive Issues: The Case of Haramaya District, Ethiopia. J. Open Innov. Technol. Mark. Complex. 2020, 6, 96. [CrossRef]

63. Fandika, I.R.; Kadyampakeni, D.M.; Zingore, S. Performance of bucket drip irrigation powered by treadle pump on tomato and maize/bean production in Malawi. Irrig. Sci. 2011, 30, 57-68. [CrossRef]

64. Elhindi, K.M.; El-Hendawy, S.; Abdel-Salam, E.; Elgorban, A.; Ahmed, M. Impacts of fertigation via surface and subsurface drip irrigation on growth rate, yield and flower quality of Zinnia elegans. Bragantia 2015, 75, 96-107. [CrossRef]

65. Mirjat, M.; Jiskani, M.; Siyal, A.; Mirjat, M. Mango production and fruit quality under properly managed drip irrigation sys-tem. Pak. J. Agric. Agric. Eng. Vet. Sci. 2011, 27, 1-12. 